\title{
Earnings Management and State Ownership: A Literature Review
}

\author{
Francesco Capalbo ${ }^{1}$, Marco Sorrentino ${ }^{2} \&$ Margherita Smarra $^{3}$ \\ ${ }^{1}$ Professor of Accounting, University of Molise, Italy \\ ${ }^{2}$ Adjunct Professor of Business Administration, Pegaso Telematic University, Italy \\ ${ }^{3} \mathrm{PhD}$ in Accounting, University of Molise, Italy \\ Correspondence: Marco Sorrentino, Adjunct Professor of Business Administration-Pegaso Telematic University, \\ Centro Direzionale - Isola F2, Naples, Italy. E-mail: marco.sorrentino@unipegaso.it
}

Received: June 28, 2017

doi:10.5539/ijbm.v13n6p117
Accepted: April 8, 2018

Online Published: May 15, 2018

\begin{abstract}
Purpose: State Owned Enterprises (SOEs) have a growing importance in the economic and social life of both developed and developing countries, being present in their key sectors such as telecommunication, electricity, transportation. The purpose of this paper is to offer a comprehensive review of the up to date literature on the relation between State Ownership and Earnings management.

Design/methodology/approach: An examination of the literature was undertaken to review the quantitative studies that analyze the existence or the non-existence of a relation between State Ownership and Earnings management, comparing population and data set used, methodology applied and result achieved. To find studies relevant to the issue, we utilized Google Scholar and delimited the research to 20 top Scholarly Journals, over the interval 1996-2016.

Findings: The available literature seems to offer contrasting viewpoints regarding the relationship between public ownership and earnings management, even though studies generally show a slight prevalence towards a negative relationship. This means that the quality of the earnings published in the budgets of public owned enterprises must be slightly higher than the earnings published by private companies.
\end{abstract}

Research limitations/implications: Almost all studies reviewed present limitations that hinder the assumption of general rules regarding the obtained results. At the same time, the different studies do not always use the same system to measure earnings management activities.

Practical implications: The paper might offer interesting implications for central and local governments, in order to influence the decisions on their intervention in the market.

Originality/value: To our knowledge, this is the first study trying to attempt this emerging goal.

Keywords: state owned enterprises, SOEs, earnings management, public ownership, literature review

\section{Introduction}

State Owned Enterprises (SOEs) have a growing importance in the economic and social life of many countries (Christiansen, 2011; OECD, 2014; Vernon \& Aharoni, 2014; Bruton et al., 2015; Subramanian, 2016; Hope \& Vyas, 2017). In its last report on the size and sectoral distribution of SOEs, OECD has proved that those entities are especially present in key sectors of the national economy of the member States such as telecommunication, electricity, transportation (OECD, 2014). In a wider study, Kowalsky et al. (2013) have showed that in non-OECD countries, SOEs explain a large part of the national GDP, reaching the astonishing level of $98 \%$ in China, $81 \%$ in Russia and being anyhow largely over $50 \%$ in Brasil, India, Malesia, Indonesia and UAE.

The debate on their performance, and especially the comparison with the performance reached by private owned entities operating in the same industries, has become central in the economic policy of both developed and developing countries and has the potential to influence the decisions of central and local governments on their intervention in the market.

But while in most cases SOEs performance is still mainly measured using accounting earnings (Bortolotti et al., 2007; Megginson \& Netter, 2001; Monteduro, 2014; Villalonga, 2000), the literature has for many years paid little attention to the impact that State Ownership might have on the frequency and magnitude of earnings 
management (Wang \& Yung, 2011; Dechow et al., 2010; Cinquini \& Tenucci, 2016) and therefore on the quality of those earnings. This is especially surprising since many studies have proved that a direct relation between ownership structure and earnings management does exist. That was the case for studies explaining the relations between earnings management and, in turn, ownership concentration (Fama and Jensen 1983; Shleifer and Vishny 1989; Hart 1995), family ownership (Wang, 2006, Jiraporn \& DaDalt, 2009), public vs private ownership (i.e. listed versus unlisted companies) (Burgsthaler et al., 2006; Ball \& Shivakumar, 2005; Givoly et al., 2010), institutional vs non institutional ownership (Jiambalvo et al., 2002) and degree of managerial ownership (Warfield et al., 1995; Lafond \& Roychowdhury, 2008; Nobuyuki \& Akinobu, 2008; Holderness, 2002).

Any study on the relation between earnings management and the degree of State Ownership would then perfectly fit in that stream of research with its results having the potential to shape appropriate comparisons between State Owned and Private owned entities performance. And indeed, in the last years those studies have firmly increased.

Against this background, the present research wishes to offer a comprehensive review of the up to date literature on the relation between State Ownership and Earnings management, comparing population and data set used, methodology applied and result achieved. To our knowledge, this is the first study trying to attempt this goal.

The remainder of this article is structured as follows. The methodology of the review is provided in Paragraph 2. Paragraph 3 offers a list of the reasons that might suggest the existence of a correlation between State Ownership and Earnings management. Paragraph 4 describes the studies that have supported the existence of a relation. Finally, the Paragraph 5 draws the conclusions.

\section{Methodology of the Review}

To find studies relevant to the issue, we utilized Google Scholar and delimited the research to the following Scholarly Journals: Accounting, Auditing \& Accountability Journal, Accounting \& Business Research, Accounting Horizons, The Accounting Review, Contemporary Accounting Research, Corporate Governance: An International Review, Journal of Accounting \& Economics, Journal of Accounting and Public Policy, Journal of Accounting Literature, Journal of Accounting Research, Journal of Business Finance \& Accounting, The Accounting Review, The Journal of Finance, Review of Accounting Studies, Journal of Accounting, Auditing \& Finance, Journal of International Accounting Research, Managerial Finance and Journal of Financial Economics. In particular, we searched the articles having in the abstract both the following terms: "State Owned Enterprises" or "SOE" and "earnings management", over the interval 1996-2016.

Not all the articles returned by that search have been quoted in the study that has reported just those supporting either the existence or the non-existence of a relation between State Ownership and Earnings management. At the same time, when any of those papers has made an explicit reference to other studies directly tackling the issue, also the latter have been included in the study.

\section{Reasons that Might Suggest the Existence of a Relation between State Ownership and Earnings Management}

There are at least six main reasons that might suggest the existence of a positive correlation between State Ownership and Earnings Management:

1) Public sector entities are flanked by a generally lower level of governance and audit quality (Alchian \& Albert, 1977; Shleifer, 1998) and such a condition is typically associated with an increase in managerial autonomy that, in turn, might ease the engagement in earnings management activities (Smith, 1976);

2) In SOEs, the accountability chain is usually longer and wider than it is in the private owned entities and this is likely to result in an increase of the incentives to manipulate accounting data. It is longer because the State owning an Entity, while is a principal in respect of SOEs managers (the agents), is also an agent in respect of the community that ultimately bears the risks and accrues the benefits arising from SOEs activities. It is wider, because SOEs managers are directly accountable not just towards the owners but also towards a variety of stakeholders, such as citizens, public opinion, public expenditure control bodies (Sinclair, 1995), and in a wider sense, anyone in whose interest such companies should always operate (Parker \& Gould, 1999).

3) SOEs managers may be subject to different and often contrasting interests due to the influence of different powerbases reflected in the ownership (Ghosh \& Whalley, 2008, Bruton et al., 2015), so that they have to manage a range of conflicting views that potentially encourage data manipulation and lay the foundations for an increase in earnings management activities. 
4) The breakdown of damage possibly deriving from earnings management on a larger number of people increases the likelihood that this occurs as the probability of careful control of accounts and performance is lower (Jones, 1991).

5) The normally lower technical level of SOEs accounting data recipients might increase the likelihood of earnings management. Previous literature has indeed proved that earnings management is negatively correlated with the technical knowledge of recipients (Rajgopai et al. 1997; Koh 2003).

6) As no managerial ownership can ever exist in SOE (Wang and Yung 2011), it is impossible to expect that those entities might solve the earnings management problem through the alignment of the interests of both the agent and the principal (Dempsey et al., 1993; Warfield et al., 1995) (Note 1).

There are also convincing reasons that might suggest the existence of a negative correlation:

1) As widely used in literature to explain the greater quality of financial data produced by listed companies (Ball \& Shivakumar 2005), the greater attention paid to SOEs results as well as the greater number and variety of stakeholders is likely to result in an overall improvement in the quality of the financial statements (Burgstahler \& Dichev, 1997). An improvement that, according to several studies (Botosan, 1997; Sengupta, 1998; Bhattacharya et al., 2003), is likely to be rewarded in terms of better conditions to raise capitals on the market thus creating one more incentive to reduce earnings management.

2) The higher probability of public scrutiny by a large number of subjects including owner representatives, consumer associations, citizens advice bureaus, members of public spending control bodies, and non-specialist media representatives, is likely to make earnings management activities less appealing.

3) In many national contexts, the consequences of tampering with SOEs accounting data can be for the preparer by far more serious than those occurring in the private sector. A financial statements alteration that damages the interests of a private company can for example be resolved through a settlement between the parties, as all are interested in reaching an agreement rather than starting legal proceedings. Instead, where such alterations are discovered by a public owned company, reconciliation is much more difficult - if not statutorily impossible - to achieve (Capalbo et al., 2014).

4) In many SOEs the appointment and eventual confirmation of managers is a predominantly political issue. In a context where relationships count more than results, the stimulus for data alteration is much lower. If the reasons for nomination, renewal or even dismissal are not linked to a company's economic results the interest in embarking upon complex and risky earnings management proceedings decline. Very often SOEs managers are politicians or ex-politicians who act as such rather than as businessmen (Cheng et al., 2015), and who expect to be evaluated predominantly for political reasons than for their financial or economic results (Fan et al., 2007).

5) Minimising taxes, that is probably one the main incentives explaining earnings management in private owned and especially in managerial owned companies, is likely to be less relevant in SOEs. In most cases, the tax outflow of the entity is, indeed, a tax inflow for its owner.

\section{Studies Supporting a Relationship between Earnings Management and State Ownership}

\subsection{Studies Supporting a Negative Relationship between Earnings Management and State Ownership}

One of the first work on earnings management in state owned enterprises is that of Aharony et al. (2000). The authors analysed the financial statements of 83 Chinese state-owned companies before and after Initial Public Offers (IPO) compiled between 1992 and 1995, and found evidence of an increase in ROA during the IPO year that was more pronounced when regulations were fewer - therefore indicating earnings management activities. In addition, the authors demonstrated how these activities are less prevalent in protected sectors where industries may be favoured by the State, and there are consequently fewer reasons to augment income levels for IPO purposes (Note 2). The work, in line with successive research results (Jian \& Wong 2003, Chen \& Yuan 2004, Chen et al., 2008, Aharony et al., 2010), confirms the existence of earnings management activities in Chinese state owned enterprises but does not explain if, and in what measure, this evidenced behaviour depends upon the public nature of ownership. The obtained results have not been compared with the behaviour of privately owned companies at the same time under the same circumstances. Neither would it be useful to make a comparison with the results from other international researchers conducted on earnings management during the IPO, because the authors recognised that the protectionist behaviour held by the Chinese Government and the extreme typicality of conditions characterising the IPO of companies in that country would deprive any such comparison of significance. The work of Aharony et al. (2010) has been completed by a more recent research made by Cheng et al. (2015), which again analysed earnings management around the IPO period for Chinese companies, but this 
time they offer a direct comparison between the behaviour of companies in public ownership and the behaviour of privately owned companies. The analysis was carried out on data from 2003 to 2009 that involved 437 companies, comprising 177 publicly owned and 260 privately owned companies, and uses a slightly amended version of the model developed by Jones to measure earnings management. The results indicate greater evidence of discretionary accrual data for private companies, leading the authors to conclude that a negative relationship between public ownership and earnings management exists (Note 3 ).

Ding et al. (2007) and Wang and Yung (2011) also arrived at a negative relationship conclusion. Ding et al. (2007) compared earnings management in a group of 142 privately owned listed companies with the same number of publicly owned enterprises; the relative status of the companies was distinguished by considering the public or private nature of the major shareholder. The analysis utilises data from a single year (2002), and uses two proxies for the measurement of earnings management: a) discretionary accruals developed via the Jones model (1991), and b) non-operating income/sales used to measure the effect of non-market-based non-operating related party transactions, such as property sales. The results show privately owned firms have an increased tendency to promote budgetary policies designed to inflate final results as opposed to publicly owned companies, therefore leading to a conclusion confirming the existence of a negative relationship between public ownership and earnings management. The authors feel, however, that the results strongly reflect the specific nature of the Chinese market, where weaker and less developed private companies feel a greater need to present positive results.

Wang and Yung (2011), through an analysis of 557 listed Chinese companies between 1998 and 2006, also found evidence of a negative relationship between state owned enterprises and earnings management. In particular, the authors demonstrated that discretionary accruals decrease as public ownership increases, but this correlation disappears after 2002 with the advent of the free market. The authors believe that the negative relationship between public ownership and earnings management is not completely linked to a particularly efficient company management, but instead to two environmental specifics: a) the role of the Chinese government in dissuading opportunistic behaviour within public owned enterprises; b) the particular type of protection afforded to publicly owned companies that evidently reduces the pressure on economic results. In this case, the authors again evidence the impossibility of exporting such results to different contexts, because of the heavy conditioning deriving from the absolute typicality of the Chinese market and, above all, the regulations established for listing and delisting public companies within this market. Due to this market typicality, the authors concluded their study with a specific call for future research and advocated that similar research studies should be undertaken in other countries.

Capalbo et al. (2014) responded to the call, using unlisted Italian public service companies as the study reference, where they find a negative relationship in the sense that earnings management activities appear to reduce with an increase in the percentage of public ownership. The analysis used a sample of 5,349 companies and studied annual budget sheets issued over a four-year period between 2009 and 2012. The sample contained 1,457 State owned entities (SOE) with at least $30 \%$ of shares being public property, and 3,892 private owned entities (POE) where public owned shares were under $30 \%$, and earnings management was calculated for all companies for the three-year period between 2010-2012. Earnings management activities were measured using a model developed by Stubben (2010) based on investigation of the adopted alterations and consequent gains. The author holds that revenues are an ideal component to measure the instrumental use of discretion, since they are one of the main balance sheet items and anticipated or postponed measurements, or those that are not in line with the GAAP, can generate significant profit variations in the direction the budget editors hoped for. To measure the effects of these instrumental measurements, Stubben (2010) proposed a model that compares the credit variations with revenue variations and, after checking the model to also take into account a number of variables such as the size and age of the company, profitability and sector, went on to measure earnings management on the basis of unexpected or abnormal receivables. The results evidence how earnings management activities are generally less intense in privately owned companies and are negatively related to public ownership. In addition, the results show that such activities decrease with company growth and increase with greater profitability. As it is limited to a single national reality, the work is of course affected by possible influences inherent to the regulatory environment, as well as any limitations resulting from the specific nature of the utilities sector, and particularly the intense relationships which companies in this sector may have with the public administrations holding the shares, including commercial transactions. However, the results are of particular importance for two reasons: a) the choice of public service sector gives a relatively homogeneous population of companies with which to analyse the impact that public ownership may have on the frequency and extent of earnings management activities, and provides a useful benchmark regarding the behaviour of competing private companies (Tan 2002); b) the study 
refers to unlisted companies and therefore allows the analysis to be isolated from the effects that company listing may have on earnings management activities, as mentioned above.

The negative relationship between public ownership and earnings management is also confirmed in a study on Vietnamese listed companies carried out by Hoang et al. (2014), in which the behaviour of 150 listed companies between 2005 and 2011 was considered, and earnings management measured in terms of the quality of accruals (Dechow and Dichev 2002). In this case, the authors also divided the study population into two panels based on the percentage of shares in public ownership, establishing $30 \%$ as the distinguishing point between SOEs and private companies, arriving at a total of 71 and 79 bodies respectively. The results, which were obviously affected by the small size of the sample, veer toward a negative relationship between public ownership and earnings management.

\subsection{Studies Supporting a Positive Relationship between Earnings Management and State Ownership}

Less numerous, but no less relevant, are the studies that conclude by confirming the existence of a positive relationship. Guo and Ma (2015) measured earnings management in 1,176 listed Chinese companies between 2004 and 2010 through the use of the Dechow and Dichev (2002) model that permits an accrual quality evaluation of relative to cash flow trend. The authors believe that earnings management is favoured in the SOEs context by the number and variety of interests held by representatives of public companies at different ownership levels, and this interpretation is supported by a reduction in earnings management when central government is the principal shareholder. Analogous results were seen by Chen et al. 2008 when analysing the behaviour of all Chinese listed companies between 1994 and 2000 by measuring earnings management via the frequency by which the ROE is placed just under established regulatory borderlines. They concluded that there was a positive relationship between public shareholders and earnings management activities, above all when dealing with local administrations. The authors stress the direct interest that local politicians may often have regarding the results of companies that are either controlled by their administrations or represented by the success that these companies achieve, especially when dealing with listed companies that are in line with the personal interests of the local politicians. Positive relationships have also been found outside China. Ben-Nasr et al. (2015) analysed 250 companies in different countries with reference to those that had been recently privatised, and found that when governments were permanent shareholders there was an increase in earnings management activities. This is the so-called political interference hypothesis according to which the State has greater incentives to reduce budget quality in order to hide the effects of potential tunnelling activities put in place to promote the destination of corporate resources to political objectives. In other words, when the State retains ownership of privatised companies, it does so for ulterior political reasons and the investments are more easily hidden in lower quality balance sheets. Evidence of a positive relationship has also been found in Italy. Poli (2015) published a study conducted on a sample of 13,724 unlisted companies working in different sectors between 2012-2014 and measuring earnings management through the results distribution method developed by Burgstahler and Dichev (1997). The author concludes by confirming the existence of a positive relationship between public ownership and earnings management. Commenting on the difference between the results achieved in the previous research of Capalbo et al. (2014), the author believes that due to the different methodology adopted, the results definitely suffer from the lower level of efficiency of Italian public companies and the desire to avoid the considerations that overly positive or negative results may raise both in public opinion and in higher levels of government (Poli 2015).

\section{Conclusions}

To summarise, the available literature seems to offer contrasting viewpoints regarding the relationship between public ownership and earnings management, even though studies generally show a slight prevalence towards a negative relationship. This means that the quality of the earnings published in the budgets of public owned enterprises must be slightly higher than the earnings published by private companies. Almost all studies, however, present limitations that hinder the assumption of general rules regarding the obtained results. It must be remembered that many are linked to a Chinese context, which for multiple reasons has unique characteristics. Many others are linked to the experience of single national contexts that while less peculiar than the Chinese ones, still exhibit a high level of typicality. Still others, even when referencing global contexts, are related to exceptional events such as privatisation or listing. Last but not least, the different studies do not always use the same system to measure earnings management activities, as illustrated in the following table. 
Table 1. Synopsis of the results attained by literature on the subject of the relationship between earnings management and public ownership

\begin{tabular}{|c|c|c|c|}
\hline Authors & Sample Population & EM measurement system & $\begin{array}{lr}\text { Earnings } & \text { Management and } \\
\text { public } & \text { ownership } \\
\text { relationship } & \\
\end{array}$ \\
\hline Aharony et al. (2000) & $\begin{array}{l}83 \text { Chinese state owned companies } \\
\text { before and after initial public } \\
\text { offerings, carried out between } 1992 \\
\text { and } 1995\end{array}$ & Increase of ROA in the IPO year & Not specifically analysed \\
\hline Ding et al. (2007) & $\begin{array}{l}142 \text { privately owned companies with } \\
\text { the same number of publicly owned } \\
\text { companies for } 2001 \text { and } 2002\end{array}$ & $\begin{array}{l}\text { discretionary accruals using Jones } \\
\text { model (1991) and the non-operating } \\
\text { income/sales relationship used to } \\
\text { measure the effect of non-market-based } \\
\text { non-operating related party } \\
\text { transactions }\end{array}$ & Negative \\
\hline Cheng et al. (2015) & $\begin{array}{l}437 \text { companies, } 177 \text { public and } 260 \\
\text { private, between } 2003 \text { and } 2009\end{array}$ & $\begin{array}{l}\text { discretionary accruals using a modified } \\
\text { Jones model }\end{array}$ & Negative \\
\hline Wang and Yung (2011) & $\begin{array}{l}557 \quad \text { Chinese listed companies } \\
\text { between } 1998 \text { and } 2006\end{array}$ & $\begin{array}{l}\text { discretionary accrual using a modified } \\
\text { Jones model }\end{array}$ & $\begin{array}{l}\text { Negative up to } 2002 \text { (year of } \\
\text { the free market) }\end{array}$ \\
\hline Capalbo et al (2014) & $\begin{array}{l}5,349 \text { companies, including } 1,457 \\
\text { State owned entities (SOE), for the } \\
\text { period } 2010-2012\end{array}$ & $\begin{array}{l}\text { discretionary receivables using the } \\
\text { Stubben model (2010) }\end{array}$ & Negative \\
\hline Hoang et al. (2014) & $\begin{array}{l}150 \text { Vietnamese listed companies } \\
\text { between } 2005 \text { and } 2011\end{array}$ & $\begin{array}{l}\text { abnormal accruals using the Dechow } \\
\text { and Dichev model (2002) }\end{array}$ & Negative \\
\hline Guo e Ma (2015) & $\begin{array}{l}1,176 \text { Chinese listed companies } \\
\text { between } 2004 \text { and } 2010\end{array}$ & $\begin{array}{l}\text { accruals quality based on Dechow and } \\
\text { Dichev model (2002) }\end{array}$ & Positive \\
\hline Chen et al. (2008) & $\begin{array}{l}\text { All Chinese listed companies between } \\
1994 \text { and } 2000\end{array}$ & $\begin{array}{l}\text { Positioning ROE just under determined } \\
\text { regulatory borderlines }\end{array}$ & Positive \\
\hline Poli (2015) & $\begin{array}{l}13,724 \text { companies for the period } \\
2012-2014\end{array}$ & $\begin{array}{l}\text { results distribution method developed } \\
\text { by Burgstahler and Dichev (1997) }\end{array}$ & Positive \\
\hline Ben-Nasr et al. (2015) & $\begin{array}{l}250 \text { international companies subject to } \\
\text { recent privatisation during the period } \\
1990-2000\end{array}$ & $\begin{array}{l}\text { abnormal accruals determined on the } \\
\text { basis of the Dechow and Dichev model } \\
(2002) \text { as modified by Ball and } \\
\text { Shivakumar (2005) to include the } \\
\text { effects of timely loss recognition }\end{array}$ & Positive \\
\hline
\end{tabular}

\section{References}

Aharony, J., Lee, C. W. J., \& Wong, T. J. (2000). Financial packaging of IPO firms in China. Journal of Accounting Research, 38(1), 103-126. http://www.jstor.org/stable/2672924

Aharony, J., Wang, J., \& Yuan, H. (2010). Tunnelling as an incentive for earnings management during the IPO process in China. Journal of Accounting and Public Policy, 29(1), 1-26. https://doi.org/10.1016/j.jaccpubpol.2009.10.003

Alciatore, M., Dee, C. C., Easton, P., \& Spear, N. (1998). Asset write-downs: A decade of research. Journal of Accounting Literature, 17(1), 1-39.

Altamuro, J., Beatty, A. L., \& Weber, J. (2005). The effects of accelerated revenue recognition on earnings management and earnings informativeness: Evidence from SEC Staff Accounting Bulletin No. 101. The Accounting Review, 80(2), 373-401. https://doi.org/10.2308/accr.2005.80.2.373

Azzini, L., (1957). Le situazioni d'impresa investigate nella dinamica economia delle produzioni. Milano: A. Giuffrè.

Ball, L., \& Shivakumar, L. (2005). Earnings quality in UK private firms: comparative loss recognition timeliness. Journal of Accounting and Economics, 39(1), 83-128. https://doi.org/10.1016/j.jacceco.2004.04.001

Ball, R., \& Brown, P. (1968). An empirical evaluation of accounting income numbers. Journal of Accounting Research, 159-78. DOI: 10.2307/2490232 
Ball, R., (2009). Market and political/regulatory perspectives on the recent accounting scandals. Journal of Accounting Research, 47(2), 277-323. https://doi.org/10.1111/j.1475-679X.2009.00325.x

Beatty, A. L., Ke, B., \& Petroni, K. R. (2002). Earnings management to avoid earnings declines across publicly and privately held banks. The Accounting Review, 77(3), 547-70. https://doi.org/10.2308/accr.2002.77.3.547

Beaver, W. H. (1968). Market prices, financial ratios, and the prediction of failure. Journal of Accounting Research, 179-92. https://doi.org/10.2307/2490233

Beneish, M. D. (1999). The detection of earnings manipulation. Financial Analysts Journal, 55(5), 24-36.

Beneish, M. D. (2001). Earnings management: A perspective. Managerial Finance, 27(12), 3-17. https://doi.org/10.1108/03074350110767411

Ben-Nasr, H., Boubakri, N., \& Cosset, J. C. (2015). Earnings quality in privatized firms: The role of state and foreign owners. Journal of Accounting and Public Policy, 34(4), 392-416. https://doi.org/10.1016/j.jaccpubpol.2014.12.003

Bergstresser, D., \& Philippon, T. (2006). CEO incentives and earnings management. Journal of Financial Economics, 80(3), 511-29. https://doi.org/10.1016/j.jfineco.2004.10.011

Bhattacharya, U., Daouke, H., \& Welker, M. (2003). The world price of earnings opacity. The Accounting Review, 78(3), 641-78. https://doi.org/10.2308/accr.2003.78.3.641

Bhaumik, S. K., \& Gregoriou, A. (2010). Family’ Ownership, Tunnelling and Earnings Management: A Review of the Literature. Journal of Economic Surveys, 24(4), 705-30. https://doi.org/10.1111/j.1467-6419.2009.00608.x

Bortolotti, B., De Jong, F., Nicodano, G., \& Schindele, I. (2004). Privatization and Stock Market Liquidity. Journal of Banking \& Finance, 31(2), 297-316.

Botosan, C. A. (1997). Disclosure level and the cost of equity capital. Accounting Review, 72(3), 323-349.

Bruton, G.D., Peng, M.W., Ahlstrom, D., Stan, C., \& Xu, K. (2015). State-owned enterprises around the world as hybrid organizations. The Academy of Management Perspectives, 29(1), 92-114. https://doi.org/10.5465/amp.2013.0069

Burgstahler, B. C., Hail, L., \& Leuz, C. (2006). The Importance of Reporting Incentives: Earnings Management in European Private and Public Firms. The Accounting Review, 81(5), 983-1016. https://doi.org/10.2308/accr.2006.81.5.983

Burgstahler, D., \& Dichev, I. (1997). Earnings management to avoid earnings decreases and losses. Journal of Accounting and Economics, 24(1), 99-126. https://doi.org/10.1016/S0165-4101(97)00017-7

Burgstahler, D., \& Eames, M. (2000). Management of earnings and analyst forecast. $23^{\text {rd }}$ European Accounting Association annual congress. Munich.

Capalbo, F., Frino, A., Mollica, V., \& Palumbo, R. (2014). Accrual-based earnings management in state owned companies: Implications for transnational accounting regulation. Accounting, Auditing \& Accountability Journal, 27(6), 1026-40. https://doi.org/10.1108/AAAJ-06-2014-1744

Chen, C., Shi, H., \& Xu, H. (2013). Underwriter Reputation, Issuer Ownership, and Pre-IPO Earnings Management: Evidence from China. Financial Management, 42(3), 647-77. https://doi.org/10.1111/fima.12006

Chen, K. C., \& Yuan, H. (2004). Earnings management and capital resource allocation: Evidence from China's accounting-based regulation of rights issues. The Accounting Review, 79(3), 645-65. https://doi.org/10.2308/accr.2004.79.3.645

Chen, X., Lee, C. W. J., \& Li, J. (2008). Government assisted earnings management in China. Journal of Accounting and Public Policy, 27(3), 262-74. https://doi.org/10.1016/j.jaccpubpol.2008.02.005

Cheng, C. A., Wang, J., \& Wei, S. X. (2015). State ownership and earnings management around initial public offerings: Evidence from China. Journal of International Accounting Research, 14(2), 89-116. https://doi.org/10.2308/jiar-51193

Christiansen, H. (2011). The size and composition of the SOE sector in OECD countries. OECD Publishing.

Cinquini, L., \& Tenucci, A. (2016). Strategic management accounting and business strategy: A loose coupling? Journal of Accounting \& Organizational Change, 6(2), 228-59. 
https://doi.org/10.1108/18325911011048772

Coronella, S. (1997). Riserve e annacquamenti patrimoniali occulti. Rivista italiana di ragioneria e di economia aziendale, (1-2), 47-49.

DeAngelo, L. E. (1986). Accounting numbers as market valuation substitutes: A study of management buyouts of public stockholders. Accounting Review, 61(3), 400-20.

Dechow, P. M., \& Dichev, I. D. (2002). The quality of accruals and earnings: The role of accrual estimation errors. The Accounting Review, 77(s-1), 35-59. https:// doi.org/10.2308/accr.2002.77.s-1.35

Dechow, P. M., Sloan, R. G., \& Sweeney, A. P. (1995). Detecting earnings management. Accounting Review, 70(2), 193-225.

Dechow, P. M., Sloan, R. G., \& Sweeney, A. P. (1996). Causes and consequences of earnings manipulation: An analysis of firms subject to enforcement actions by the sec. Contemporary Accounting Research, 13(1), 1-36. https://doi.org/10.1111/j.1911-3846.1996.tb00489.x

Dechow, P., Gee, W., \& Schrand, C. (2010). Understanding earnings quality: A review of the proxies, their determinants and their consequences. Journal of Accounting and Economics, 50(2), 344-401. https://doi.org/10.1016/j.jacceco.2010.09.001

DeFond, M. L., \& Jiambalvo, J. (1994). Debt covenant violation and manipulation of accruals. Journal of Accounting and Economics, 17(1-2), 145-76. https://doi.org/10.1016/0165-4101(94)90008-6

Degeorge, F., Patel, J., \& Zeckhauser, R. (1999). Earnings management to exceed thresholds. Journal of Business, 72(1), 1-33.

Dempsey, S. J., Hunt, H. G., \& Schroeder, N. W. (1993). Earnings management and corporate ownership structure: An examination of extraordinary item reporting. Journal of Business Finance \& Accounting, 20(4), 479-500. https://doi.org/10.1111/j.1468-5957.1993.tb00270.x

Demski, J.S., Patell, J.M., \& Wolfson, M.A. (1984). Decentralized choice of monitoring systems. Accounting Review, 59(1), 16-34.

Ding, Y., Zhang, H., \& Zhang, J. (2007). Private vs State Ownership and Earnings Management: evidence from Chinese listed companies. Corporate Governance: An International Review, 15(2), 223-38.

Dyck, A., \& Zingales, L. (2004).Private benefits of control: An international comparison. The Journal of finance, 59(2), 537-600. https://doi.org/10.1111/j.1540-6261.2004.00642.x

Elliott, J. A., \& Hanna, J. D. (1996). Repeated accounting write-offs and the information content of earnings. Journal of Accounting Research, 34(Supplement), 135-55. https://doi.org/10.2307/2491430

Fama, E. F., \& French, K. R. (1997). Industry costs of equity. Journal of Financial Economics, 43(2), 153-93.

Fama, E.F., \& Jensen, M.C. (1983). Separation of ownership and control. The Journal of Law and Economics, 26(2), 301-25. https://doi.org/10.1086/467037

Fan, J. P., Wong, T. J., \& Zhang, T. (2007). Politically connected CEOs, corporate governance, and Post-IPO performance of China's newly partially privatized firms. Journal of Financial Economics, 84(2), 330-57. https://doi.org/10.1016/j.jfineco.2006.03.008

Ferrero, G., (1965). Le determinazioni economico-quantitative d'azienda. Milano: Giuffrè Editore.

Fields, T. D., Lys, T. Z., \& Vincent, L. (2001). Empirical research on accounting choice. Journal of Accounting and Economics, 31(1), 255-307. https://doi.org/10.1016/S0165-4101(01)00028-3

Francis, J. R., \& Ke, B. (2006). Disclosure of fees paid to auditors and the market valuation of earnings surprises. Review of Accounting Studies, 11(4), 495-523. https://doi.org/10.1007/s11142-006-9014-z

Gaver, J. J., \& Gaver, K. M. (1998). The relation between nonrecurring accounting transactions and CEO cash compensation. Accounting Review, 73(2), 235-53.

Ghosh, M., \& Whalley, J. (2008). State owned enterprises, shirking and trade liberalization. Economic Modelling, 25(6), 1206-15. https://doi.org/10.1016/j.econmod.2008.03.005

Givoly, D., Hayn, C. K., \& Katz, S. P. (2010). Does Public Ownership of Equity Improve Earnings Quality?. The Accounting Review, 85(1), 195-225. https://doi.org/10.2308/accr.2010.85.1.195

Grossi, G., Papenfuß, U., \& Tremblay, M. S. (2015). Corporate governance and accountability of state-owned enterprises: relevance for science and society and interdisciplinary research perspectives. International 
Journal of Public Sector Management, 28(4/5), 274-85. https://doi.org/10.1108/IJPSM-09-2015-0166

Gul, F. A., Leung, S., \& Srinidhi, B. (2000). Efficient Management of Earnings to Signal Growth Opportunities An Empirical Investigation. Working Paper, City University of Hong Kong.

Guo, F., \& Ma, S. (2015), Ownership characteristics and earnings management in China. The Chinese Economy, 48(5), 372-95. http://dx.doi.org/10.1080/10971475.2015.1067086

Hart, O. (1995). Corporate Governance: Some Theory and Implications. The Economic Joural, 103(430), 678-689. https://doi.org/10.2307/2235027

Healy, P. M. (1985). The effect of bonus schemes on accounting decisions. Journal of Accounting and Economics, 7(1-3), 85-107. https://doi.org/10.1016/0165-4101(85)90029-1

Healy, P., \& Wahlen, J. (1999). A Review of the Earnings Management Literature and Its Implications for Standard Setting. Accounting Horizons, 13(4), 365-383. https://doi.org/10.2308/acch.1999.13.4.365

Hoang, T., Abeysekera, I., \& Ma, S. (2014). State ownership and earnings management: empirical evidence from Vietnamese listed firms. Faculty of Business - Papers

Holderness, C. G. (2002). A Survey of blockholders and corporate control. Federal Reserve Bank of New York Economic Policy Review, 1-15.

Holthausen, R. W., \& Verrecchia, R. E. (1990). The effect of informedness and consensus on price and volume behaviour. Accounting Review, 191-208.

Hope, O. K., \& Vyas, D. (2017). Private company finance and financial reporting. Accounting and Business Research, 47(5), 506-537. http://dx.doi.org/10.1080/00014788.2017.1303963

Hunt, H. G., \& Hogler, R. L. (1990). Corporate Ownership and accounting choice: a critical analysis. Critical Perspectives on Accounting, 1, 53-67.

Jaggi, B. (2002). Earnings management response to debt covenant violations and debt restructuring. Journal of accounting auditing and finance, 17(4), 295-324.

Jensen, M. C., \& Meckilng, W. H. (1976). Theory of the Firm: Managerial Behaviour, Agency Costs and Ownership Structure. Journal of Financial Economics, 3(4), 306-60. https://doi.org/10.1016/0304-405X(76)90026-X

Jiambalvo, J., Rajgopal, S., \& Venkatachalam, M. (2002). Institutional ownership and the extent to which stock prices reflect future earnings. Contemporary Accounting Research, 19(1), 117-45. https://doi.org/10.1506/EQUA-NVJ9-E712-UKBJ

Jian, M., \& Wong, T. (2003). Earnings management and tunneling through related party transactions: Evidence from Chinese corporate groups. Doctoral dissertation. http://dx.doi.org/10.2139/ssrn.424888

Jiraporn, P., \& DaDalt, P. J. (2009). Does founding family control affect earnings management? Applied Economics Letters, 16(2), 113-19. http://dx.doi.org/10.1080/17446540701720592

Jones, J. J. (1991). Earnings management during import relief investigations. Journal of Accounting Research, 29(2), 193-228.

Kim, J. B., \& Yi, C. H. (2006). Ownership structure, business group affiliation, listing status, and earnings management: Evidence from Korea. Contemporary Accounting Research, 23(2), 427-64. https://doi.org/10.1506/7T5B-72FV-MHJV-E697

Klein, A. (2002). Audit committee, board of director characteristics, and earnings management. Journal of Accounting and Economics, 33(3), 375-400. https://doi.org/10.1016/S0165-4101(02)00059-9

Koh, P. S. (2003). On the association between institutional ownership and aggressive corporate earnings management in Australia. The British Accounting Review, 35(2), 105-28. https://doi.org/10.1016/S0890-8389(03)00014-3

Kothari, S., Leone, A. J., \& Wasley, C. E. (2005). Performance matched discretionary accrual measures. Journal of Accounting and Economics, 39(1), 163-97. https://doi.org/10.1016/j.jacceco.2004.11.002

Kowalski, P., Büge, M., Egeland, M., \& Sztajerowska, M. (2013). State-Owned Enterprises: Trade Effects and Policy Implications. OECD Trade Policy Papers n. 147, Paris: OECD Publishing.

Lafond, R., \& Roychowdhury, S. (2008). Managerial Ownership and Accounting Conservatism. Journal of Accounting Research, 46(1), 101-35. https://doi.org/10.1111/j.1475-679X.2008.00268.x 
Leuz, C., Nanda, D., \& Wysocki, P.D. (2003). Earnings management and investor protection: an international comparison. Journal of Financial https://doi.org/10.1016/S0304-405X(03)00121-1

Levitt, A. (1998). The numbers game. Speech delivered at the NYU Center for Law and Business, New York.

Liu, J., \& Thomas, J. (2000), Stock returns and accounting earnings. Journal of Accounting Research, 38(1), 71-101. http://dx.doi.org/10.2139/ssrn.139419

Liu, Q., \& Lu, Z. (2007). Corporate governance and earnings management in the Chinese listed companies: A tunneling perspective. Journal of Corporate Finance, 13(5), 881-906. https://doi.org/10.1016/j.jcorpfin.2007.07.003

Loudder, M.L., \& Behn, B.K. (1995). Alternative Income Determination Rules and Earnings Usefulness: The Case of R\&D Costs. Contemporary Accounting Research, 12(1), 185-205. https://doi.org/10.1111/j.1911-3846.1995.tb00486.x

Luke, B. (2010). Examining accountability dimensions in state owned enterprises. Financial Accountability \& Management, 26(2), 134-62. https://doi.org/10.1111/j.1468-0408.2010.00496.x

Man, C. K., \& Wong, B. (2013). Corporate governance and earnings management: A survey of literature. Journal of Applied Business Research (JABR), 29(2), 391-418.

Markarian, G., Pozza, L., \& Prencipe, A. (2008). Capitalization of R\&D costs and earnings management: Evidence from Italian listed companies. The International Journal of Accounting, 43(3), 246-67. https://doi.org/10.1016/j.intacc.2008.06.002

Masini, C. (1979). Lavoro e risparmio, Torino: UTET.

McNichols, M., \& Wilson, G. P. (1988). Evidence of earnings management from the provision for bad debts. Journal of Accounting Research, 26, 1-31.

Megginson, W. L., \& Netter, J. M. (2001). From State to Market: A Survey of Empirical Studies on Privatization. Journal of Economic Literature, 39(2), 321-389.

Monteduro, F. (2014). Public-private versus public ownership and economic performance: evidence from Italian local utilities. Journal of Management \& Governance, 18(1), 29-49. https://doi.org/10.1007/s10997-012-9235-4

Nobuyuki, T., \& Akinobu, S. (2008). Managerial Ownership and Earnings Management: Theory and Empirical Evidence from Japan. Journal of International Financial Management and Accounting, 19(2). https://doi.org/10.1111/j.1467-646X.2008.01018.x

OECD. (2014). The size and sectoral distribution of SOEs in OECD and Partner Countries. OECD publishing,

Onida, P. (1974). Il bilancio dell'impresa. Le sue differenziazioni e la sua interpretazione. Milano: Giuffrè Editore.

Osma, B. G. (2008). Board independence and real earnings management: the case of R\&D expenditure. Corporate Governance: An International Review, 16(2), 116-31. https://doi.org/10.1111/j.1467-8683.2008.00672.x

Peasnell, K. V., Pope, P. F., \& Young, S. (2000). Detecting earnings management using cross-sectional abnormal accrual models. Accounting and Business Research, 30(4), 313-26. http://dx.doi.org/10.1080/00014788.2000.9728949

Poli, S. (2015). Do Ownership Structure Characteristics Affect Italian Private Companies' Propensity to Engage in the Practices of "Earnings Minimization" and "Earnings Change Minimization"? International Journal of Economics and Finance, 7(6), 193-207. http://dx.doi.org/10.5539/ijef.v7n6p193

Provasoli, A. (1974). Il bilancio d'esercizio destinato a pubblicazione. Milano: Giuffrè Editore.

Quagli, A., Avallone, F., \& Ramassa, P. (2007). Stock option plans in Italy: Does earnings management matter. SSRN. http://dx.doi.org/10.2139/ssrn.955469

Rajgopal, S., Venkatachalam, M., Balakrishnan, T. C., McNichols, M., \& Nelson, K. (1997). The Role of Institutional Investors in Corporate Governance: An Empirical Investigation. Graduate School of Business, Stanford University.

Ronen, J., \& Sadan, S. (1981). Smoothing Income Numbers: Objectives, Means and Implications 
Addison-Wesley Paperback Series in Accounting.

Ronen, J., \& Yaari, V. (2008). Earnings management. New York: Springer.

Sankar, M. R., \& Subramanyam, K. (2001). Reporting discretion and private information communication through earnings. Journal of Accounting Research, 39(2), 365-86. https://doi.org/10.1111/1475-679X.00017

Schipper, K. (1989). Commentary on earnings management. Accounting Horizons, 3(4), 91-102.

Scott, W. R. (2003). Financial accounting theory. Prentice Hall Upper Saddle River, NJ.

Sengupta, P. (1998). Corporate disclosure quality and the cost of debt. Accounting Review, 73(4), 459-74.

Shleifer, A., \& Vishny, R.W. (1989). Management entrenchment: The case of manager-specific investments. Journal of Financial Economics, 25(1), 123-39. https://doi.org/10.1016/0304-405X(89)90099-8

Stubben, S. R. (2010). Discretionary Revenues as a Measure of Earnings Management. The Accounting Review, 85(2), 695-717. https://doi.org/10.2308/accr.2010.85.2.695

Subramanian, S. (2016). A Comparison of Corporate Governance Practices in State-owned Enterprises and Their Private Sector Peers in India. IIM Kozhikode Society \& Management Review, 5(2), 200-16. https://doi.org/10.1177/2277975215617268

Suh, Y. S. (1990). Communication and income smoothing through accounting method choice. Management Science, 36(6), 704-23. https://doi.org/10.1287/mnsc.36.6.704

Sweeney, A. P. (1994). Debt-covenant violations and managers' accounting responses. Journal of Accounting and Economics, 17(3), 281-308. https://doi.org/10.1016/0165-4101(94)90030-2

Tan, J. (2002). Impact of ownership type on environment-strategy linkage and performance: Evidence from a transitional economy. Journal of Management Studies, 39(3), 333-54. https://doi.org/10.1111/1467-6486.00295

Teo, S., \& Wong, T. (1993). Perceived auditor quality and the earnings response coefficients. The Accounting Review, 68, 346-67.

Trueman, B., \& Titman, S. (1988). An explanation for accounting income smoothing. Journal of Accounting Research, 26, 127-39. DOI: 10.2307/2491184

Venkatachalam, M., Rajgopal, S., \& Bowen, R. M. (2008). Accounting Discretion, Corporate Governance, and Firm Performance. Contemporary Accounting Research, 25(2), 351-405. https://doi.org/10.1506/car.25.2.3

Vernon, R., \& Aharoni, Y. (2014). State-Owned Enterprise in the Western Economies. Routledge Revivals, Routledge.

Villalonga, B. (2000). Privatization and efficiency: differentiating ownership effects from political, organizational, and dynamic effects. Journal of Economic Behavior \& Organization, 42(1), 43-74.

Wang, D. (2006). Founding Family Ownership and Earnings Quality. Journal of Accounting Research, 44(3), 619-56. https://doi.org/10.1111/j.1475-679X.2006.00213.x

Wang, L., \& Yung, K. (2011). Do State Enterprises Manage Earnings More than Privately Owned Firms? The Case of China. Journal of Business Finance \& Accounting, 38(7-8), 794-812. https://doi.org/10.1111/j.1468-5957.2011.02254.x

Warfield, T. D., Wild, J. J., \& Wild, K. L. (1995). Managerial ownership, accounting choices, and informativeness of earnings. Journal of Accounting and Economics, 20(1), 61-91. https://doi.org/10.1016/0165-4101(94)00393-J

Watts, R. L., \& Zimmerman, J. L. (1978). Towards a positive theory of the determination of accounting standards. Accounting Review, 53(1), 112-34.

Watts, R.L., \& Zimmerman, J.L. (1990). Positive accounting theory: a ten year perspective. Accounting Review, $131-56$.

Zappa, G. (1957). Le produzioni nell'economia delle imprese. Milano: Giuffrè Editore.

Zucca, L.J., \& Campbell, D. R. (1992). A closer look at discretionary writedowns of impaired assets. Accounting Horizons, 6(3), 30-41. 


\section{Notes}

Note 1. Warfield et al. (1995) analysed the behaviour of 1,600 companies and discovered that discretionary accruals in companies with a degree of managerial ownership under 5\% was practically double the amount traceable in companies with a degree of managerial ownership greater than $35 \%$.

Note 2. Successive studies have confirmed the existence of earnings management activities in Chinese companies in occasion of initial public offers. Using a sample of 185 companies listed on the Shanghai Stock Exchange during the period 1999-2001, Aharony et al. (2010) have shown that related-party transactions are used to inflate the results during the periods preceding the IPO and that motivation increases due to the prospect of tunnelling activities used to exploit the resources of minority shareholders for the benefit of the parent company.

Note 3. On the theme of IPO in the Chinese context, Chen et al. (2013) demonstrate that the positive effect that is normally exerted by underwriters on the quality of company balance sheets exists only in cases of listed private companies and is much less in the cases of public owned companies.

\section{Copyrights}

Copyright for this article is retained by the author(s), with first publication rights granted to the journal.

This is an open-access article distributed under the terms and conditions of the Creative Commons Attribution license (http://creativecommons.org/licenses/by/4.0/). 